\title{
Deindustrialization: Entries and Exits in Declining Industries: The Greek Experience
}

\author{
Sormas Asterios \\ Business Administration Department, Technological Educational Institute of Western Macedonia, Greece
}

Copyright $\mathrm{C} 2017$ by authors, all rights reserved. Authors agree that this article remains permanently open access under the terms of the Creative Commons Attribution License 4.0 International License

\begin{abstract}
Deindustrialization, a developed countries phenomenon, is a process where the industrial activity in a region or in an industrial sector is reduced due to economic or social change. Usually occurs because an industrial activity is no longer economically viable. Economists have made enormous efforts to understand the process of developing markets, but only a few studies have been published for the opposite. This research deals with the disinvestment, the decision making process ending to the market exit. The life cycle law applies in industries as the birth of an idea, to the development and peak and finally the death. Entries and exits in declining industries are interesting; approaching the determinants they dominate the economic decisions. In the introduction, the data derived from official authorities related to the Greek manufacturing industry for a period of twenty (20) years. The classification of all manufacturing sectors, based on certain criteria, leads to the sectors suffering the most from deindustrialization. The study is focusing in the 87 firms (almost all population) of the Textile Dyeing and Finishing sub-sector. An econometric model is built to test three (3) hypotheses and arrive into the conclusions of the determinants affecting entries and exits in the declining industry.
\end{abstract}

JEL: L1

Keywords Declining Industries, Divestment

\section{Introduction}

The idea of this paper lies on the last paragraph of conclusions of the M. Lieberman's paper (RAND, 1990), "Exit from declining industries: Shake out or Stakeout?" where he addresses to other researchers to confirm his findings. So, the effort was to confirm or supplement them with an analogous case.

The closest case to me was the deindustrialization process of the Greek manufacturing industry. Studying the process of the Greek deindustrialization or divestment, I needed to find the most crucial factors driving the Greek manufacturing companies to the exit.

The first step was to check all (15) Greek manufacturing sectors, to ascertain which one showed significant rate of divestment. Setting five criteria and applying OLS, I reached to a classification of all sectors and the champion was the Textile Industry.

Secondly, was all textile industry deindustrialized? The answer was No. So, I needed to do deeper analysis, going to the subsectors. Here, the same methodology was applied as before. Five criteria, least square method, classification and the champion was the Dyeing and Finishing industry.

In the third step, I collected the balance sheets of 87 dyeing and finishing companies (employing over 20 persons) for 20 years. From the balance sheets 30 variables arose, which gathered in relative groups and regressed against EXIT. The statistically significant variables of every group regressed again and finally created a group of seven statistically significant variables. On them I applied a robustness test, which showed that the significance is valid.

Several conclusions were reached, some of which first appear in literature and others are the same with the M. Lieberman's paper.

Below classification criteria will be presented and then a brief presentation of the Dyeing and Finishing sub-sector. In the next chapter is presented the econometric model with the hypotheses to be tested and finally the conclusions.

\section{Sector Classification Criteria}

The study is based on data derived from the fifteen (15) sectors of the Greek manufacturing industry, issued by the Hellenic Statistical Authority. The data collected refer to the period between 1993 and 2003 and are relating to the following areas:

- The number of firms active in the sector.

- The quantity of their production.

- The gross production value.

- The sales value. 
- The number of employees.

- The wages.

- The average wage per employee.

- The total investment.

All figures are expressed in Euros and are deflated on base year $1999(=100)$.

In order to classify each sector, the least square method was applied to find the slope of the line $(y=a+b x)$.

The classification criteria used for each sector were,

1. Firms lost.

2. Job positions lost.

3. Goss production slope (b).

4. Sales slope (b).

5. Investment slope (b).

All criteria are gathered in the following Table 1. It is clear that the sectors with the poorest performance are the Leather, Textile and Clothing industries. More specifically:

The Leather Industry lost in a decade (1993 - 2003) 150 firms that is $61.2 \%$ of the total, 3,445 job positions, had gross production value $\mathrm{b}=-5.7699$, sales $\mathrm{b}=-6.5345$ and investment $\mathrm{b}=-2.2832$.
The Textiles lost 253 firms that is $48.2 \%$ of the total, 11,089 jobs $(39,7 \%)$, with production $b=-3.1724$, sales $b=$ -3.3427 and investment $b=4.2254$.

The Clothing lost 565 firms that is $62.5 \%$ of the total, 21,630 jobs $(59.6 \%)$, with production $b=-2.5438$, sales $b=$ -3.8866 and investment $b=-6.5768$.

Thus, it is required, further, four-digit analysis of the sub-sectors, of the above mentioned industries. Actually, there are three (3) subsectors in the Leather industry, eight (8) in Textiles and another eight (8) in Clothing. At this point, the least square method is applied again on data regarding:

- Production

- Sales

- $\quad$ Deflated sales values (base year 1999).

The study concludes that Textile Dyeing and Finishing appears to be the poorest sub-sector. Actually, Dyeing and Finishing represents an almost vertical decline in production, with $\mathrm{b}=-9.6740$ (it is known that: $-10<\mathrm{b}<10$ ) and sales decline with $\mathrm{b}=-3.0330$.

Table 1. Sectors of the Greek Manufacturing Industry $1993-2003$.

\begin{tabular}{|c|c|c|c|c|c|}
\hline \multicolumn{7}{|c|}{ Classification criteria } \\
\hline & Criterion I & Criterion II & Criterion III & Criterion IV & Criterion V \\
\hline SECTOR & Firms Lost & Job Positions Lost & Production b & Sales b & Investment b \\
\hline Food and Beverages & -368 & -747 & 3,2155 & 1,1387 & 3,7156 \\
\hline Textile & -253 & -11089 & $-3,1724$ & $-3,3427$ & 4,2254 \\
\hline Clothing & -565 & -21630 & $-2,5438$ & $-3,8866$ & $-6,5768$ \\
\hline Leather & -150 & -3445 & $-5,7699$ & $-6,5345$ & $-2,2832$ \\
\hline Wood & -77 & -1447 & 2,9001 & $-2,3184$ & 8,3173 \\
\hline Paper & -31 & -334 & 2,3268 & 2,5387 & 8,3651 \\
\hline Prints & -24 & 3751 & 1,2938 & 2,1501 & 4,9979 \\
\hline Chemicals & -95 & -5849 & 2,0147 & 1,4064 & 6,4466 \\
\hline Plastics & -54 & 1099 & 3,7673 & 4,0289 & 1,3166 \\
\hline Nonmetallic Minerals & -144 & -2479 & 1,1342 & 1,2461 & 8,9849 \\
\hline Metalls & -18 & 1604 & 5,3397 & 6,2511 & 2,1354 \\
\hline Metallic Products & -96 & 1762 & 2,556 & 3,0222 & 5,4763 \\
\hline Machinery & -112 & 180 & 3,5713 & 3,9372 & 3,5416 \\
\hline Electric Appliances & -25 & -366 & 2,8023 & 2,9629 & 6,7727 \\
\hline Furniture & -180 & -1802 & 6,2599 & 6,4566 & 2,9787 \\
\hline
\end{tabular}




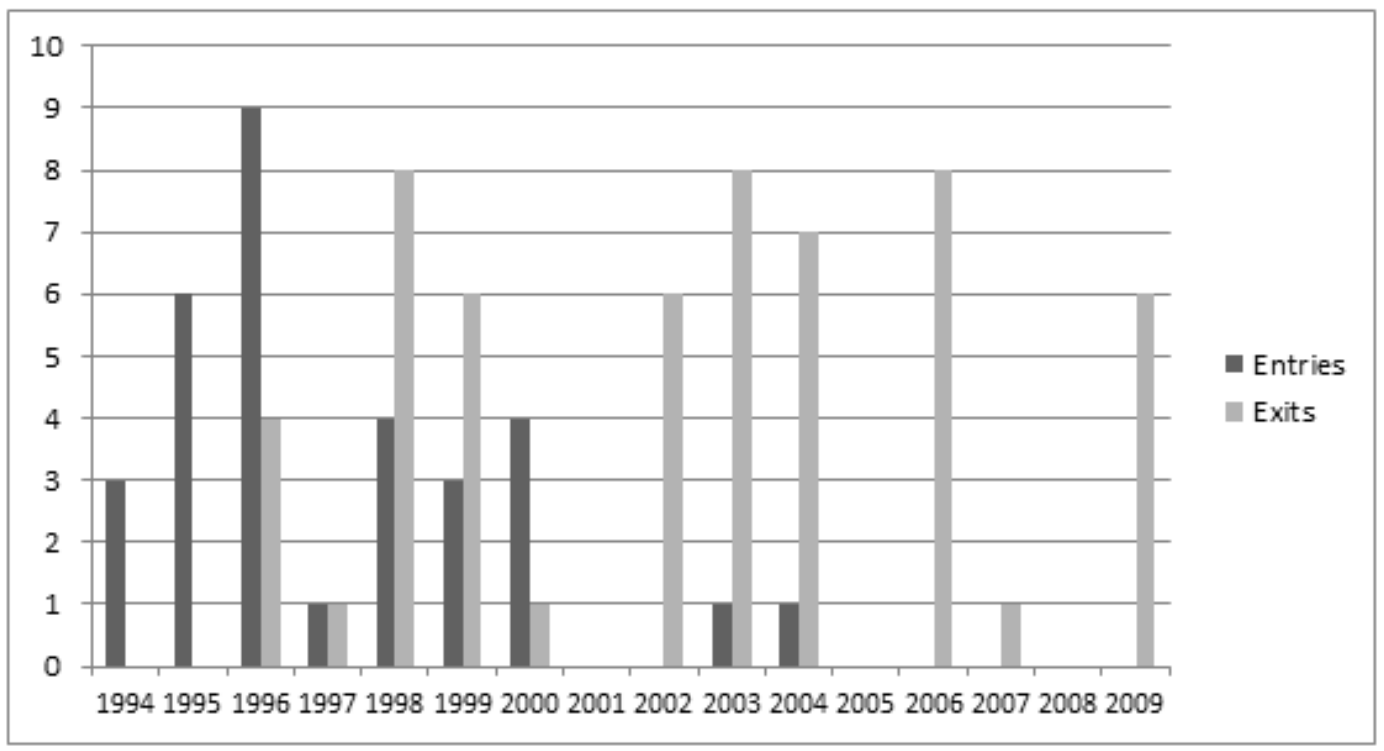

Figure 1. Textile dyeing and finishing industry entries and exits $1999-2009$

\section{The Textile Dyeing and Finishing Sub-sector}

In the database, the firm is considered as a statistical unit and it is defined as an operational unit making decisions and operating in a certain location. Exit, is considered (generally) when a firm doesn't continue to appear in the database. All data were gathered from the firm level. As a matter of fact, all the balance sheets were gathered from the firms that employed more than twenty (20) persons. For every firm and for all the respective years being active in the market publishing financial statements, a table was drafted with the information derived from them, accompanied with a series of financial ratios, for the period 1999 to 2009. In this period 86 firms had been active. In 1993 there were 53 firms in the market. The interim years entered the market 34 firms. In 2009, 29 firms continued produce. In 2009, only 16 firms or $18 \%$ of the firms remained active in comparison to those being active in 1999 .

\section{The Econometric Model}

Generally, the factors affecting the exit of the market are the profits and the industrial development, as they studied by Caves and Porter (1976) [1] and Karakaya and Stahl (1991) [2], but exit patterns are substantially different among the industries. Here the dependent variable is the exit pattern of the declining dyeing and finishing industry. Also, have to be examined the endogenous and on the firm level factors leading them out of market.

It has to be tested if equity is an exit factor, in a declining industry. According to the economic theory, lack of capital, especially in a declining sector where the demand is gradually diminishing, is an exit factor and as a variable is expected to bear negative sign. Usually, lack of funds is supplemented by borrowing, so, the relation between debt-equity funds has to be tested.

Hypothesis $\mathbf{1}^{\text {st }}$ : Lack of equity, especially in a declining sector, leads firms to exit.

Almost, all empirical models contain the scale economics variable, which always are statistically significant, influencing exits and entries. Here, in a model of a declining sector, it is attempted to light its behavior if influences the exits.

Hypothesis $2^{\mathrm{d}}$ : In a declining sector, scale economies are an exit factor.

The receivables from customers not collected in a reasonable period of time, in a declining industry are considered an exit factor, along with its inventories.

Hypothesis $3^{\mathrm{d}}$ : the receivables and the inventories in a declining industry are exit factors.

The econometric model will be approached with a non-linear model. Common model is the probit model. This model is based in the latent variable I, which is going to replace the dependent variable EXIT of the present model. It can be represented in vector format as:

$$
\mathbf{I}=\mathbf{X a}+\boldsymbol{\mu}
$$

The dichotomous variable EXITS when equals 0 expresses the firm exit from the market and when equals to 1 , they stay in the market. So, it will be:

$$
\begin{aligned}
& \text { EXIT }=1 \text { if } \mathrm{I}>0 \\
& \text { EXIT }=0 \text { if } \mathrm{I}<0
\end{aligned}
$$

The probability $\mathrm{P}_{\mathrm{i}}$ to occur EXIT $=1$, can be calculated as:

$$
\mathbf{P}_{\mathbf{i}}=\mathbf{P}(\mathbf{E X I T}=\mathbf{1})=\mathbf{P}[\mathrm{Xa}+\boldsymbol{\mu}>\mathbf{0}]=\mathbf{P}[\boldsymbol{\mu}>-\mathrm{Xa}]
$$

Given that, the residuals are normally distributed, the normal distribution can be used to calculate the probabilities 
$\mathrm{P}_{\mathrm{i}}$.

The regression equation will be the following:

$$
\begin{array}{rl}
\text { EXIT }=a_{0}+a_{1} & C O M P+a_{2} \text { TYPE }+a_{3} \text { AREA }+a_{4} \text { YEAR } \\
& +a_{5} \text { OPER }+a_{6} \text { NFAssets } \\
& +a_{7} \text { AnInvest }+a_{8} \text { AccumInv } \\
& +a_{9} \text { AnDepress }+a_{10} \text { NInvest } \\
& +a_{11} \text { Inventory }+a_{12} \text { Receivab } \\
& +a_{13} \text { Cash }+a_{14} \text { Tassets }+a_{15} \text { Cap } \\
& +a_{16} \text { STLiab }+a_{17} \text { LTLiab } \\
& +a_{18} \text { Tliabilit }+a_{19} \text { Sales }+a_{20} \text { COGS } \\
& +a_{21} \text { EBIT }+a_{22} \text { Staff }+a_{23} \text { LabProd } \\
& +a_{24} \text { Tprod }+a_{25} \text { DebtAs } \\
& +a_{26} \text { FAsTurn }+a_{27} \text { AgFAsset } \\
& +a_{28} \text { AssetTurn }+a_{29} \text { GrProfit } \\
& +a_{30} \text { RonCapE }+a_{31} \text { AvCollect } \\
& +a_{32} \text { ReceivTurn }+a_{33} \text { InvTurn } \\
& +a_{34} \text { Liquid }+a_{35} \text { Scalecon }+\mu
\end{array}
$$

Symbol explanation:

COMP: each one of the 86 companies of the sample, employing over 20 workers.

TYPE: autonomous or vertically integrated dyeing and finishing company.

AREA: the prefecture where the company is located.

YEAR: every year from 1993 to 2009.

OPER: the operational situation of the company. If it is in operation, it is noted by 1 , if it changed sector by 2 , if it is in inaction by 3 , if it is bankrupt by 4 , if it was merged by 5 .

NFAssets: Net fixed assets. They are exit - entry barrier because of their duration and specialization and the majority of them become sunk costs.

AnInvest: annual investment.

AccumInv: the accumulated investment.

AnDepres: the annual depreciations.

NInvest: the net investment

Inventory: as mentioned in hypothesis 3 , it is expected with negative sign because they are an exit factor.

Receivab: the receivables which are also an exit factor.

Cash: lack of cash usually leads firms to the exit.

Tassets: total assets.

Cap: the equity, which is expected with negative sign, because if they are inadequate they are exit factor [A. Kleijweg \& M. Lever (1996) [3], T. Pamukcu, K. Sekkat, E. Taymaz (2010)] [4].

STLiab: short term liabilities.

LTLiab: long term liabilities.

Sales:

COGS: cost of goods sold.

EBIT: earnings before income tax.

LabProd: the ratio sales over the number of employees.
Tprod: total productivity, sales minus cost of goods sold over the number of employees.

DebtAs: the relation between the foreign assets and equity, is the ratio of short term liabilities minus long term liabilities over equity.

FasTurn: fixed asset turnover is a ratio showing the degree of utilization of fixed assets. It provides an indication of fixed assets overinvestment. High ratio is intense utilization while low overinvestment. The ratio is sales over net fixed assets.

AgFAssets: aging fixed assets is a ratio that helps to estimate the age of fixed assets and their possible replacement. It is accumulated investment over accumulated investment minus net fixed assets.

AssetTurn: asset turnover is a ratio to estimate the degree of utilization of assets by the firm in order to achieve the targeted sales.

GrProfit: gross profits are sales minus cost of goods sold over sales. It is expected with negative sign, because a decline in profits may lead firms to the exit. Theoretically, would be expected that low profits would increase exits, but this relation has not been confirmed from the empirical findings. Siegfrid \& Evans, (1994) [5] believe that profitability is not related with the exit patterns. But if the entrepreneurs have other objectives than to maximize profits may remain on market even though they earn less (Hamilton B. H., 2000) [6]. Nevertheless, there is an empirical study of the Swedish manufacturing industries that shows the relation between profitability and the decision to exit that the less profitable businesses were more likely to close Kristina Nystrom, (2007) [7].

RonCapE: return of capital earning is earning before income taxes over equity.

AvCollect: average receipts collected (in days) is average receivables x 365 over annual sales.

ReceivTur: receivables turnover is the sales over the average receivables

InvTurn: inventory turnover is the sales over the average inventories. High ratio indicates liquidity.

Liquid: the liquidity as a fraction of inventories + receivables + cash over short-term liabilities.

Scalecon: the economies of scale as a fraction of sales over net assets. Usually scale economics mean a great amount of investment when the firm entered the market. Some of these assets have no alternative use, becoming sunk costs. The presence of sunk costs usually discourages or delays the exit, becoming a firm idle. It was found in this study that, out of 86 firms studied, 47 (78,3\%) bankrupted, $10(16,6 \%)$ are idle waiting an increase in demand, 2 of them $(3,3 \%)$ changed activities and one $(1,6 \%)$ firm was merged. 
Practically, it is difficult to be regressed together all 28 independent variables. There is need to create smaller groups with common characteristics, in order to be distinguished the most statistically important variables. Finally, all these variables will be regressed against the depended variable (y) EXIT

\section{Group I}

The sunk costs of fixed assets can influence the decision for exiting the market in highly specialized types of industrial process, because they were designed only for this use. According to Harrigan [8] obsolete fixed assets are exit barrier.

Net assets, net investment, total assets, fixed assets turnover ratio and aging fixed assets ratio.

The regression equation and the results will be:

$$
\text { Exit }=\mathrm{a}+\text { NFASSETS }+ \text { NINVEST }+ \text { TASSETS }+
$$$$
+ \text { FASTURN + AGFASSETS }
$$

\begin{tabular}{|ccccc|}
\hline Variable & Coefficient & Std. Error & t-Statistic & Prob. \\
\hline C & 0.632246 & 0.120608 & 5.242 .154 & 0.0000 \\
NFASSETS & $2.76 \mathrm{E}-08$ & $1.59 \mathrm{E}-08$ & 1.736 .052 & 0.0826 \\
NINVEST & $2.09 \mathrm{E}-09$ & $1.07 \mathrm{E}-08$ & 0.195457 & 0.8450 \\
TASSETS & $-2.29 \mathrm{E}-08$ & $8.58 \mathrm{E}-09$ & -2.669 .266 & 0.0076 \\
FASTURN & 0.048403 & 0.017446 & 2.774 .433 & 0.0055 \\
AGFASSET & -0.963225 & 0.213021 & -4.521 .745 & 0.0000 \\
\hline Mean dependent var & 0.565116 & S.D. dependent var & 0.496030 \\
S.E. of regression & 0.484760 & Akaike info & criterion & 1.329 .500 \\
Sum squared resid & 2.006 .837 & Schwarz criterion & 1.362 .688 \\
Log likelihood & -5.656 .849 & Hannan-Quinn \\
criter. & 1.342 .205 \\
\hline
\end{tabular}

Indeed, as follows from the theory, net fixed assets with 1.736 are exit barriers also the fixed asset turnover is another exit barrier (2.7744), inasmuch as there are great investments in this particular industry. It looks like there is no competition in the industry, since the aging fixed assets $(-4.5217)$ seems to be obsolete and the total assets with -2.6692 are exit factor.

\section{Group II}

In a firm low performances represent the most powerful divestment ratio according Dranikoff et al, (2002) [9], Duhaime \& Grant (1984) [10], Harrigan (1981) (1982) [8], Markides C. C. (1992) [11], Montgomery \& Thomas (1988) [12], Pashley \& Phillipatos (1990) [13]. The lowest performance has been measured in the returns on equity, productivity and profits before taxes. Also, low performances are related with the intensity of debt, which was found to trigger closings [Chang R. \& Velasco A., (1998) [14], Duhaine \& Grant (1984) [10].

The above suggests that it would be worth a deeper study of the entire balance sheet in every one of the firms in the sample.
Second group of variables includes capital, receivables and cash.

$$
\text { Exit }=\mathrm{a}+\mathrm{CAP}+\text { RECEIVAB }+\mathrm{CASH}
$$

\begin{tabular}{|ccccc|}
\hline Variable & Coefficient & Std. Error & t-Statistic & Prob. \\
\hline C & 0.306080 & 0.052733 & 5.804 .365 & 0.0000 \\
CAP & $-1.49 \mathrm{E}-08$ & $7.60 \mathrm{E}-09$ & -1.953 .156 & 0.0508 \\
RECEIVAB & $-1.31 \mathrm{E}-09$ & $1.33 \mathrm{E}-08$ & -0.098300 & 0.9217 \\
CASH & $-9.05 \mathrm{E}-08$ & $7.00 \mathrm{E}-08$ & -1.292 .954 & 0.1960 \\
\hline Mean dependent var & 0.567630 & S.D. dependent var & 0.495692 \\
S.E. of regression & 0.489382 & $\begin{array}{c}\text { Akaike info } \\
\text { criterion }\end{array}$ & 1.348 .818 \\
Sum squared resid & 2.062 .053 & $\begin{array}{c}\text { Schwarz criterion } \\
\text { Hannan-Quinn } \\
\text { criter. }\end{array}$ & 1.370 .842 \\
Log likelihood & -5.793 .639 & 1.357 .248 \\
\hline
\end{tabular}

In the industry, capital with $(-1.9531)$ are inadequate leading firms to the exit. The same conclusion was reached by Segara, Arauzo, Martin [15], studying the Spanish manufacturing. Also, according to the barrier symmetry hypothesis (Caves \& Porter, (1977) [16], it is possible that in the Greek textile dyeing and finishing industry during the period between 1990 and 2010, the inadequacy of capital are the cause and the reason leading the firms to the exit.

\section{Group III}

A thought and a question: "Does the industry withstand a continuous renewal investment of the process equipment, in the shallow Greek market, despite the exporting efforts?" Probably, the accumulated investments are an exit factor and are going to be studied in combination with the annual depreciation, the asset turnover and the returns of capital earnings.

\begin{tabular}{|c|c|c|c|c|}
\hline Variable & Coefficient & $\begin{array}{l}\text { Std. } \\
\text { Error }\end{array}$ & t-Statistic & Prob. \\
\hline $\mathrm{C}$ & 0.127395 & 0.074118 & 1.718 .827 & 0.0856 \\
\hline ACCUMINV & $-2.90 \mathrm{E}-08$ & $6.11 \mathrm{E}-09$ & -4.747 .536 & 0.0000 \\
\hline ANDEPRES & $2.23 \mathrm{E}-08$ & $1.64 \mathrm{E}-08$ & 1.357 .816 & 0.1745 \\
\hline ASSETTURN & 0.226126 & 0.071931 & 3.143 .643 & 0.0017 \\
\hline RONCAPE & -0.114589 & 0.067661 & -1.693 .565 & 0.0903 \\
\hline $\begin{array}{c}\text { Mean } \\
\text { dependent var }\end{array}$ & 0.565116 & \multicolumn{2}{|c|}{ S.D. dependent var } & 0.496030 \\
\hline $\begin{array}{l}\text { S.E. of } \\
\text { regression }\end{array}$ & 0.486312 & \multicolumn{2}{|c|}{ Akaike info criterion } & 1.329 .152 \\
\hline $\begin{array}{l}\text { Sum squared } \\
\text { resid }\end{array}$ & 2.022 .066 & \multicolumn{2}{|c|}{ Schwarz criterion } & 1.356 .809 \\
\hline $\begin{array}{c}\text { Log } \\
\text { likelihood }\end{array}$ & -5.665 .355 & \multicolumn{2}{|c|}{ Hannan-Quinn criter. } & 1.339 .740 \\
\hline
\end{tabular}

$$
\begin{aligned}
\text { Exit } & =\mathrm{a}+\text { ACCUINV }+ \text { ASSETTURN }+ \\
& + \text { RONCAPE }+ \text { ANDEPRESS }
\end{aligned}
$$

Paradoxically, the accumulated investments (- 4.7475) appeared to be cause of exit instead of barrier of exit, while the returns on capital earnings (-1.6940) in a declining industry as the Greek dyeing and finishing industry, it is expected to be exit cause. Conversely, the asset turnover 
(3.1436) is exit barrier. Firm owners understand the liquidation difficulties of their fixed assets, since they are designed for a specific process and in thus remain trapped in idle status suffering the fixed costs, hoping for a market recovery.

\section{Group IV}

A series of ratios indirectly related with liquidity and at the same time characterizing the firm's performance are: the average receipts collected, the receivables turnover and the inventory turnover. All three show the operation of the commercial department, also, they interpret the demand in the industrial sector. An increase in competition is expected in a declining industry, where the demand is constantly diminishing. A first step on the firm's side is the reduction of prices and a second, is that would attract or keep the costumers, would be the broadening of credit, i.e. extra days for the payment of invoices. This will be accompanied by a relative increase of inventories, derived from the fear of lost sales. It is therefore interesting to study the circuit in inventories and credit, because such an unhealthy situation will certainly lead in tough decision making with regards to the future of firms in the industry.

$$
\begin{gathered}
\text { Exit }=\mathrm{a}+\text { AVCOLLECT }+ \text { RECEIVTUR }+ \text { INVTURN }+ \\
\text { INVENTORY }
\end{gathered}
$$

\begin{tabular}{|ccccc|}
\hline Variable & Coefficient & $\begin{array}{c}\text { Std. } \\
\text { Error }\end{array}$ & t-Statistic & Prob. \\
\hline C & -0.063322 & 0.079711 & -0.794403 & 0.4270 \\
AVCOLLECT & $-2.32 \mathrm{E}-06$ & $4.07 \mathrm{E}-06$ & -0.570417 & 0.5684 \\
RECEIVTUR & 0.122387 & 0.026528 & 4.613 .488 & 0.0000 \\
INVTURN & 0.001172 & 0.001873 & 0.625810 & 0.5314 \\
INVENTORY & $-3.91 \mathrm{E}-08$ & $1.15 \mathrm{E}-08$ & -3.383 .189 & 0.0007 \\
\hline Mean dependent var & 0.565116 & $\begin{array}{c}\text { S.D. dependent } \\
\text { var }\end{array}$ & 0.496030 \\
S.E. of regression & 0.486685 & $\begin{array}{c}\text { Akaike info } \\
\text { criterion }\end{array}$ & 1.336 .735 \\
Sum squared resid & 2.025 .171 & $\begin{array}{c}\text { Schwarz criterion } \\
\text { Hannan-Quinn } \\
\text { criter. }\end{array}$ & 1.364 .392 \\
Log likelihood & -5.697 .960 & H.37.323 \\
\hline
\end{tabular}

Receivables turnover (4.6134) are a strong exit barrier. The collection of receivables in a declining industry is a trap that captures the firm owners, forcing them to stay in the market, even if they had made an exit decision. The receivables turnover in the dyeing and finishing industry for the years 1993 and 1994 was 125 days since the sale was made. In 2001 the average receipts collected was 420 days.

The other statistically significant variable of this group is inventories (-3.3831) and they are a cause of exit. At this point, is important to take a look at the relation between inventories and sales, to confirm the finding of -3.3831 as a cause of exit. Increased inventories result in limitation of the required liquidity and the next step will be bank loan. 1993 inventories are the $15 \%$ of the sales, while in 2009 the percentage is over $30 \%$.

\section{Group V}

Fifth group studies the variables belonging to the liabilities. Variables are: short term and long term liabilities, total liabilities and the ratio DEBT/ASSETS, the relation between foreign assets and equity.

\section{Exit $=\mathbf{a}+$ STLIAB + LTLIAB + TLIABILIT + DEBTAS}

\begin{tabular}{|ccccc|}
\hline Variable & Coefficient & Std. Error & t-Statistic & Prob. \\
\hline C & 0.192166 & 0.059219 & 3.245 .023 & 0.0012 \\
STLIAB & $6.98 \mathrm{E}-08$ & $1.68 \mathrm{E}-08$ & 4.162 .427 & 0.0000 \\
LTLIAB & $4.66 \mathrm{E}-08$ & $2.54 \mathrm{E}-08$ & 1.835 .913 & 0.0664 \\
TLIABILIT & $-3.57 \mathrm{E}-08$ & $7.51 \mathrm{E}-09$ & -4.758 .663 & 0.0000 \\
DEBTAS & 0.033568 & 0.018126 & 1.851 .913 & 0.0640 \\
\hline Mean dependent var & 0.565116 & S.D. dependent var & 0.496030 \\
S.E. of regression & 0.484064 & $\begin{array}{c}\text { Akaike info } \\
\text { criterion }\end{array}$ & 1.331 .939 \\
Sum squared resid & 2.003 .419 & Schwarz criterion & 1.359 .596 \\
Log likelihood & -5.677 .339 & Hannan-Quinn \\
criter. & 1.342 .527 \\
\hline
\end{tabular}

Short term liabilities (4.1624), long term liabilities (1.8359) and foreign assets to equity ratio (1.8519) are entry barriers, while total liabilities (-4.7586) as expected, is cause of exit.

\section{Group VI}

Productivity

\begin{tabular}{|c|c|c|c|c|c|c|}
\hline Variable & \multicolumn{2}{|c|}{ Coefficient } & \multicolumn{2}{|c|}{ Std. Error } & t-Statistic & Prob. \\
\hline C & \multicolumn{2}{|c|}{0.155985} & \multicolumn{2}{|c|}{0.047622} & 3.275 .457 & 0.0011 \\
\hline LABPROD & \multicolumn{2}{|c|}{$-1.86 \mathrm{E}-08$} & \multicolumn{2}{|c|}{$2.21 \mathrm{E}-07$} & -0.084356 & 0.9328 \\
\hline TPROD & \multicolumn{2}{|c|}{$9.18 \mathrm{E}-07$} & \multicolumn{2}{|c|}{$1.78 \mathrm{E}-06$} & 0.515338 & 0.6063 \\
\hline \multicolumn{2}{|c|}{ Mean dependent var } & \multicolumn{2}{|c|}{0.565116} & \multicolumn{2}{|c|}{$\begin{array}{l}\text { S.D. dependent } \\
\text { var }\end{array}$} & 0.496030 \\
\hline \multicolumn{2}{|c|}{ S.E. of regression } & \multicolumn{2}{|c|}{0.496534} & \multicolumn{2}{|c|}{$\begin{array}{l}\text { Akaike info } \\
\text { criterion }\end{array}$} & 1.375 .946 \\
\hline \multicolumn{2}{|c|}{ Sum squared resid } & \multicolumn{2}{|c|}{2.112 .903} & \multicolumn{2}{|c|}{ Schwarz criterion } & 1.392 .540 \\
\hline \multicolumn{2}{|c|}{ Log likelihood } & \multicolumn{2}{|c|}{$-5.886 .566$} & \multicolumn{2}{|c|}{$\begin{array}{l}\text { Hannan-Quinn } \\
\text { criter. }\end{array}$} & 1.382 .298 \\
\hline
\end{tabular}

Exit $=\mathbf{a}+$ LABPROD + TPROD

Productivity variables are found to be no statistically significant.

\section{Group VII}

From the Profit and Loss Account, somebody can acquire sales, cost of sales and profits. Sales are an indicator of the market competition and at the same time present the status of market demand. Profits will illuminate the performance of the firms in the industry.

$$
\text { Exit }=\mathrm{a}+\text { SALES }+ \text { COGS }+ \text { EBIT }+ \text { GRPROFIT }
$$




\begin{tabular}{|ccccc|}
\hline Variable & Coefficient & Std. Error & t-Statistic & Prob. \\
\hline C & 0.293394 & 0.053355 & 5.498 .913 & 0.0000 \\
SALES & $9.14 \mathrm{E}-08$ & $4.19 \mathrm{E}-08$ & 2.182 .852 & 0.0290 \\
COGS & $-1.27 \mathrm{E}-07$ & $4.87 \mathrm{E}-08$ & -2.612 .822 & 0.0090 \\
EBIT & $-1.52 \mathrm{E}-07$ & $4.84 \mathrm{E}-08$ & -3.144 .038 & 0.0017 \\
GRPROFIT & 0.023414 & 0.089083 & 0.262828 & 0.7927 \\
\hline Mean dependent var & 0.564610 & S.D. dependent var & 0.496097 \\
S.E. of regression & 0.487658 & $\begin{array}{c}\text { Akaike info } \\
\text { criterion }\end{array}$ & 1.340 .338 \\
Sum squared resid & 2.030 .899 & $\begin{array}{c}\text { Schwarz criterion } \\
\text { Hannan-Quinn }\end{array}$ & 1.368 .020 \\
Log likelihood & -5.706 .751 & criter. & 1.350 .936 \\
\hline
\end{tabular}

Established firms share the industry sales and sales variable (2.1828) is an entry barrier. The course of industry sales peaks in the year 2001 with over $€ 500$ million, but from 1993 to 2001 there were 31 new entries, while from 2001 to 2009 there were only 2 new entries and 36 exits (figure 1).

The cost of goods sold is exit cause (COGS -2.6128), also exit cause is earnings before income taxes (EBIT -3.1440), a finding identical to that of Caves \& Porter, 1976 [1] and Karakaya \& Stahl, 1991 [2].

\section{Group VIII}

According to Harrigan (1980) [8], the liquidity of the current assets is an entry barrier. Lack of liquidity does not allow firms to enter the market and creates asphyxiation to the established ones. But, is liquidity also an exit factor?

Finally, scale economics that theoretically are entry barrier and at the same time an exit factor. Lieberman (1990) [17] considers that small firms show high exit rates as a result of the scale economies. Lieberman's study is based on U.S. firm data. The present study's data are derived from the Greek manufacturing industries composed of small firms and very few big ones. If in an industry sector the big firms could achieve to have scale economies it is obvious that they will survive over the smaller ones.

\section{Exit $=\mathbf{a}+$ LIQUID + SCALECON}

\begin{tabular}{|c|c|c|c|c|c|c|}
\hline Variable & \multicolumn{2}{|c|}{ Coefficient } & \multicolumn{2}{|c|}{ Std. Error } & t-Statistic & Prob. \\
\hline $\mathrm{C}$ & \multicolumn{2}{|c|}{0.480366} & \multicolumn{2}{|c|}{0.077018} & 6.237 .047 & 0.0000 \\
\hline LIQUID & \multicolumn{2}{|c|}{0.032923} & \multicolumn{2}{|c|}{0.012418} & 2.651 .347 & 0.0080 \\
\hline SCALECON & \multicolumn{2}{|c|}{-0.217718} & & 30412 & -7.158 .981 & 0.0000 \\
\hline \multicolumn{2}{|c|}{ Mean dependent var } & \multicolumn{2}{|c|}{0.562720} & \multicolumn{2}{|c|}{ S.D. dependent var } & 0.496342 \\
\hline \multicolumn{2}{|c|}{ S.E. of regression } & \multicolumn{2}{|c|}{0.474532} & \multicolumn{2}{|c|}{$\begin{array}{l}\text { Akaike info } \\
\text { criterion }\end{array}$} & 1.303 .207 \\
\hline \multicolumn{2}{|c|}{ Sum squared resid } & \multicolumn{2}{|c|}{1.914 .032} & \multicolumn{2}{|c|}{ Schwarz criterion } & 1.319 .908 \\
\hline \multicolumn{2}{|c|}{ Log likelihood } & \multicolumn{2}{|c|}{$-5.528 .178$} & \multicolumn{2}{|c|}{$\begin{array}{l}\text { Hannan-Quinn } \\
\text { criter. }\end{array}$} & 1.309 .603 \\
\hline
\end{tabular}

Liquidity ratio (2.6513) appears to be entry barrier and it is considered in literature as a classical entry barrier or an exit factor (Harrigan (1980) [8]. The importance of finding for the specific branch of the manufacturing industry may ha two explanations:
- First: substantial liquidity is required to enter the market and

- Second: there is liquidity in the market. Here a question is raised: is it possible in a declining industry to have high liquidity? Probably the answer lies in the great number of exits occurred over the last years. Companies show in their balance sheets high liquidity which is not derived from their operation but from the liquidation of their fixed assets.

Scale economies are expected to operate as exit factor, since our database is constituted by small companies in a declining industry. This phenomenon is termed as "shakeout", that is, reduction or elimination of the non-efficient producers. Here, scale economies with $(-7.1589)$ are a strong exit factor indicator.

All the above statistically significant variables were regressed based on a procedure of rejecting the non-significant. The final group of statistically significant variables is the following:

\begin{tabular}{|ccccc|}
\hline Variable & Coefficient & $\begin{array}{c}\text { Std. } \\
\text { Error }\end{array}$ & t-Statistic & Prob. \\
\hline C & 0.531474 & 0.088832 & 5.982 .915 & 0.0000 \\
SCALECON & -0.171268 & 0.031831 & -5.380 .508 & 0.0000 \\
CAP & $-7.93 \mathrm{E}-08$ & $2.02 \mathrm{E}-08$ & -3.920 .612 & 0.0001 \\
TLIABILIT & $6.91 \mathrm{E}-08$ & $1.75 \mathrm{E}-08$ & 3.960 .045 & 0.0001 \\
LIQUID & 0.029710 & 0.012893 & 2.304 .320 & 0.0212 \\
ACCUMINV & $-1.85 \mathrm{E}-08$ & $9.64 \mathrm{E}-09$ & -1.920 .445 & 0.0548 \\
RECEIVAB & $-6.58 \mathrm{E}-08$ & $2.31 \mathrm{E}-08$ & -2.852 .601 & 0.0043 \\
INVENTORY & $-6.45 \mathrm{E}-08$ & $3.59 \mathrm{E}-08$ & -1.797 .544 & 0.0722 \\
\hline Mean dependent var & 0.562720 & S.D. dependent var & 0.496342 \\
S.E. of regression & 0.467805 & $\begin{array}{c}\text { Akaike info } \\
\text { criterion }\end{array}$ & 1.267 .101 \\
Sum squared resid & 1.849 .207 & $\begin{array}{c}\text { Schwarz criterion } \\
\text { Honnan-Quinn } \\
\text { criter. }\end{array}$ & 1.311 .638 \\
\hline
\end{tabular}

\section{Conclusions}

\subsection{Profitability}

According to the theory, it is expected that low profitability will increase the number of exits, but this relation has not been confirmed by the empirical findings, it seems rather unrelated with the exit factors (Siegfried \& Evans, (1994) [5].

A study for the Swedish manufacturing industry shows that low profitability companies are more likely to close. K. Nystrom finds profitability, statistically non-significant $(0.240)$ with an opposite sign of what would be expected.

In a similar study for the Turkish manufacturing companies where profitability is measured as the fraction value added minus wages over to total sales, concludes that profitability does not affect exits. The variable coefficient is 
with a positive sign and statistically non-significant $(0.63)$ (Pamukcu T., Sekkat K. \& Taymaz E (2010) [4].

Completely contrary to all the above, is the study of the determinants influencing the entries and exits in the Japanese manufacturing industry, where profitability measured -0.336 (at confidence level 1\%), Noriyuki Doi (1999) [18].

In the primary stage of the present study, where variables were classified in related groups, profitability appeared to be statistically significant (EBIT -3.1440), but in the final OLS results the variable disappeared.

\subsection{Capital}

Capital is a common variable in all empirical entry and exit studies. Capital is distinguished as intangible, when production process, patents, client relations or data bases are referred. Tangible capital, except fields, building or machinery, is also, the sunk costs, in other words the non-recovered costs made for the company establishment and its entry in the market. These costs are not a loss for the company. Behavioral Economics consider that sunk costs usually influence the economic decisions due to loss aversion. Economic experiments have shown that the sunk cost fallacy and loss aversion are common; hence economic rationality - as assumed by much of economics - is limited. The sunk cost fallacy is in game theory sometimes known as the "Concorde Fallacy", referring to the fact that the British and French governments continued to fund the joint development of Concorde even after it became apparent that there was no longer an economic case for the aircraft. The project was regarded privately by the British government as a "commercial disaster" which should never have been started and was almost cancelled, but political and legal issues had ultimately made it impossible for either government to pull out.

The regression results showed a strong negative $(-3.9206)$ and statistically significant relation between capital and exit. This finding complies with R. Greenaway, J. Gullstrand, R. Kneller (2009) [20], Arauzo J. M., Manjon M., Martin M. \& Segara A. (2010) [16] for the Spanish manufacturing industries and Kleijweg A., Lever M. (1996) [3] for the Dutch ones.

\subsection{Scale Economies}

Scale economies were measured as the fraction of sales over the net fixed assets and they were expected to have negative sign. Actually, they were (-5.3805), that is, an exit factor. The finding is similar to N. Doi (1999) [18] for the Japanese industries for the period 1981 to 1989. Also, K. Nystrom (2007) [7], in the study for the Swedish manufacturing industries, finds scale economies to be the only statistically significant variable with -2.007 . Finally, M. Lieberman (1990) [17] reaches the same conclusion where "scale economies appear negative and strongly statistically significant, confirming that bigger plants had the smaller probability to close".

\subsection{Inventories and Receivables}

The purpose of stock holding/keeping is to minimize the possibilities of depletion, because a shortage in goods will push potential customers to more reliable supply sources. Particularly in manufacturing, the absence of a component would delay the whole production process. Surely, there are costs to keeping inventories like expenses, interests and the risk of deterioration in quality or value waiting to be sold. Generally, the inventory cost is analogous to the ratio of the inventories (in stock) over the sales. The need of inventory keeping creates scale economies. Companies with a wide turnover, usually, keep a lower rate of inventories over sales; this results a decrease to the average cost of goods sold.

In the present study inventories were found to be statistically significant with negative sign $(-1.7975)$, alike to receivables (-2.8526). In a declining industry, the entrepreneur's anxiety staying active and waiting for better days, probably results in greater extension of credit to customers over the financially permissible limit. Also, this effort has a parallel reaction: more inventories keeping in order satisfying the demand.

\subsection{Accumulated Investment}

Cost structure and especially the sunk costs, influences the entry and exit of the companies [McAffe, Mialon, Mialon (2009) [20] and Hopenhayn H. A. (1992) [21]. Here, the variable of accumulated investment (-1.9204) allows the conclusion that the level of fixed assets is an exit factor, since the competition in the industry demands constant renewal of equipment.

\subsection{Liquidity and Liabilities}

Two variables with strong statistical significance and positive sign are liquidity with (2.3043) and total liabilities (3.9600). A $1 \%$ increase in liquidity results a $2.3 \%$ decrease of exit probability and a same increase in total liabilities reduces the exit probability $3.96 \%$. The two variables are related. An increase in liabilities occurs when:

- There is an increase in share capital

- There are bank loans

- There is an increase of credit limit by the suppliers

All three end up to the existence of liquidity.

\section{Acknowledgements}

This paper became a reality with the kind support and help of many individuals. I would like to express my appreciation to the three anonymous reviewers for their comments and suggestions. They have contributed substantially to improve the presentation of this study. 


\section{REFERENCES}

[1] Caves, R. E. and M. Porter, 1976, 'Barriers to Exit', in R. Masson and D. Qualls (eds.), Essays on Industrial Organization in Honor of Joe S. Bain, Cambridge, MA: Ballinger, pp. 39-69.

[2] Karakaya, F. and M. J. Stahl, 1991, Entry Barriers and Market Entry Decisions: A Guide for Marketing Executives, New York: Quorum Books.

[3] Kleijweg A., Lever M (1996), Entry and Exit in Dutch Manufacturing Industries.

[4] Pamukcu T., Sekkat K., Taymaz E., Entry, Exit and Productivity in Turkish Manufacturing Industries'. Chapter (p. 109 - 143), in book Market Dynamics and Productivity in Developing Countries (2010).

[5] Siegfried, J. J. and L. B. Evans, 1994, 'Empirical Studies of Entry and Exit: A Study of the Evidence', Review of Industrial Organization 9(2), 121- 155.

[6] Hamilton B. H. Does Entrepreneurship Pay? An Empirical Analysis of the returns of Self-Employment, The Journals of Political Economy Vol. 108, No 32000.

[7] Nystrom K. (2007), Patterns and determinants of entry and exit in industrial sectors in Sweden.

[8] Harrigan K. R. ' Strategy formulation in declining industries 'Academy of Management Review 1980, Vol. 5, No 4, 599-604.

[9] Dranikoff L. et al "Divestiture: Strategy's Missing Link" Harvard Business Review 2002.

[10] Duhaine I. M. \& Grant J. H., "Factors influencing divestment decision- making: Evidence from a field study (1984).
[11] Makrides C.C. "The economic characteristics of De-diversifying firms 1992 British Journal of Management.

[12] Montgomery C. \& Thomas A., "Divestment: Motives and Gains" 1988 Strategic Management Journal.

[13] Pashley M. M. \& Philippatos G. C., "Voluntary divestures and corporate life-cycle: some empirical evidence" 2006, Applied Economics Vol. 22.

[14] Chang R. \& Velasco A. Liquidity crises in emerging markets: Theory and Policy 1998.

[15] Arauzo J. M., Manjon M., Martin M., Segarra A. Entry and Exit in Spain: Tests of the independence, symmetry and simultaneity hypothesis 'Department of Economics, URV. (2010)

[16] Caves, R. E. and M. Porter, 1977, 'From Entry Barriers to Mobility Barriers: Conjectural Decisions and Contrived Deterrence to New Competition', Quarterly Journal of Economics 97(1), 241-261.

[17] Lieberman, M. B., 1990, 'Exit from Declining Industries: "Shakeout" or "stakeout", Rand Journal of Economics 21(4), 538-554.

[18] Noriyuki Doi, "The Determinants of Firm Exit in Japanese Manufacturing Industries" (1999).

[19] Greenaway D., Gullstrand J., Kneller R. (2009), 'Live or Let Die?, (Alternative Routes to Industry Exit.)

[20] McAffe R.P., Mialon H., Mialon S. "Do Sunk Costs Matter?" Economic Inquiry (April 2010323 - 336).

[21] Hopenhayn H. A. "Entry, Exit and Firm Dynamics in Long Run Equilibrium" Econometrica p. 1127 -50. 